\title{
フェノール樹脂の現状と将来展望
}

Current Status and Future Prospects of Phenolic Resin

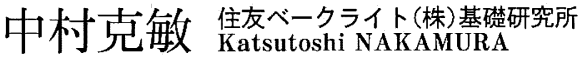

1はばめに

フェノール樹脂は長い実績に裏付けされた，信頼性の 高い熱便化性樹脂として今日まで幅広い分野で使用され ている。 コストパフォーマンスに優れており, 耐熱性, 機械強度, 電気絶縁性, クリープ特性, 寸法安定性など の特長を活かし, 各用途において新しい製品開発, 用途 展開が着実に行われている。

フェノール樹脂には，へキサメチレンテトラミンを硬 化剂として用いるノボラックと,メチロール基を反応性 官能基としてもつレゾールがある，どちらの場合も硬化 反応は縮合重合反応である，熱硬化性樹脂は，一般に低 粘度なオリゴマーを硬化反応で三次元高分子化するので 加工性が良い。

フェノール樹脂の用途は幅広いが, 成形材料, 積層品, 接着剂・結合剂等の工業用などに分類できる、これらの 用途についての現状と新規技術・トピックス, 今後の技 術動向について述べる.

\section{(2) 一ェノール樹脂の現状}

\section{2-1. 成形材料}

成形材料のグレードとしては，エンジニアリングプラ スチック（エンプラ）としてのガラス繊維強化材, 重電 機器・電気機器・車両・㕌房など汎用に使われる汎用 材, 電気・電子部品等に使用されるため硬化時にアンモ ニアガス発生のないレゾール型フェノール樹脂を用いた ノンアンモニア材などがある.
ガラス織維強化材11 は, 而熱性, 機械強度, 寸法安定性 などの特性と材料コストのバランスが良く, 熱可塑性工 ンプラと比較してもコストパフォーマンスに優れ，自動 車のエンジン周りの金属部品代替, 電装機器部品に採用 されている．さらに衝撃強度が必要な用途では，エラス トマーのブレンドによる強勒化が行われる，たとえばレ ゾール型とノボラック型の混合系でカルボキシ変性アク リロニトリルーブタジェンゴム (NBR) を混練し，モルホ ロジーを海島構造にすることによる改質2), フェノール 樹脂合成中にゴム弾性を有するエマルションあるいはラ テックスを添加し，粒径 $0.01 〜 10 \mu \mathrm{m}$ のゴム粒了を凝 集することなく分散させることによる改質引などの方法 がある.

汎用材では，低コスト化と成形性の改良が求められて おり，地道であるが着実に改良されている。

ノンアンモニア材はフェノール樹脂の耐燃性, 耐卜 ラッキング性といった安全性を活かして電気・電子部品 に広く用いられている。

最近は加工・生産性まで含めたトータルコストの低減 が着目され，樹脂を低溶融粘度かつ速硬化にして低圧で 射出成形できる材料か潤発され ${ }^{4)}$, 成形性, バリ発生等の 改良がなされている。先に述べたと㧈りフェノール樹脂 は縮合反応で硬化するため, 便化時のガス発生, 反応進 行による粘度変化があり, 射出成形条件についての/ウ 八ウが必要である。また硬化は化学反応であるため成形 サイクルが一般に長いので, 熱可塑性樹脂同等の簡易 化・ハイサイクル成形化 ${ }^{5)}$ を図るため硬化反応の精密制

表 1 フェノール樹脂生産推移（暦年）（単位： $\mathrm{t}(\%))$

\begin{tabular}{|c|c|c|c|}
\hline 種 & 1994 年 & 1995 年 & 1996 年 \\
\hline 成 形 材 料 & $57,234(0)$ & $55,961(\triangle 2)$ & $53,038(\triangle 5)$ \\
\hline 一般積層品 & $67,601(\triangle 2)$ & $59,314(\triangle 12)$ & $37,356(\triangle 37)$ \\
\hline 化粧 板 $コ$ ア & $12,777(\triangle 5)$ & $12,032(\triangle 6)$ & $12,361(3)$ \\
\hline シェルモールド用 & $38,041(\triangle 2)$ & $39,507(\quad 4)$ & $39,029(\triangle 1)$ \\
\hline 木材加工接着剤用 & $24,362(\triangle 4)$ & $25,767 i$ & $26,016(1)$ \\
\hline そ o 他 & $130,017(4)$ & 134,954 & $125,974(\triangle 6)$ \\
\hline 計 & $330,032(1)$ & $327,535(\triangle 1)$ & $293,774(\triangle 10)$ \\
\hline
\end{tabular}

[出所] 通産省化学工業統計 
御が可能となる樹脂の開発が進められている.

フェノール樹脂成形材料の成形方法は射出成形が主で あるが押し出し成形についても採用されている6!

\section{2-2. 積層品}

積層品は樹脂ワニスを紙などの基材に含浸させ，乾燥 させたプリプレグを重站合わせプレスして製造される. フェノール樹脂積層品には一般積層品と化粧板コアがあ るが, 前者の一般積層品はプリント配線板用紙基材銅張 積層板 ${ }^{7}$, 電子部品に使われる絶縁基板用紙基材積層板 がほとんどを占める．プリント配線板用では電子機器の 小型・軽量化, 多機能・高性能化に伴い狭ピッチ・高密 度配線が求められている.これに対応して, 高度な寸法 安定性, そり・私じれの極小化された材料が開発されて いる.

プリント配線板では部品取り付け孔の打ち抜き加工の 工程がある，そのため積層板には可とう性が要求され る. 可とう性化は, 乾性油をフェノール樹脂と反応させ る方法が一般的である。

量産性，簡易性の見地加ら紙基材銅張積層板を用い， 裹表の導通には印刷により貫通孔に銀ペーストを埋める 方法（銀スルーホール）がとられている. スルーホール の間隔は $1.5 \mathrm{~mm}$ 以下と狭く, 銀イオン移行による短絡 （銀マイグレーション）が起こりやすい. 対策として樹脂 を紙基材の繊維内部まで含浸することによる耐湿性の向 上が図られている゙!

また，環境に対する配慮としてハロゲン系難燃剤から ノンハロゲン系への転換む進められている

\section{2-3. 工業用}

工業用フェノール樹脂は成形材料, 積層品を除くす心゙ てのフェノール樹脂が含まれる。

(a) FRP 用 繊維強化プラスチック (FRP) はガラ スやカーボンの長瀻維またはクロスに樹脂を含浸させ て，いろいろな形状に硬化させて使用される。フェノー ル FRP は難燃性, 低発煙性, 低毒性などの特長があり, 車両, 航空機, 公共の建物の内装材用として関心があた れている，火災発生時の人身事故のほとんよ゙は発煙によ るあのであり, 安全面の見地から今後も採用が増えてい くと思われる.

(b) フォトレジスト用フフォレジストは半導体, 液晶ディスプレイ (LCD)などの素子形成に用いられる 感光性塗料である．ヒドロキシル基をあつことによる適 度なアルカリ水溶液溶解性と耐酸, 耐熱等の耐エッチン グ性を併せむつため, キノンジアジド系ポジ型フォトレ ジストのバインダーとして用いられている，半導体の高 集積化に伴い, より高感度で高解像度なフォトレジスト が求められており, フェノール樹脂の分子量, 分子量分 布, 異性体比, 核間結合位置を高度に制御する合成法の
研究が進められている.

（c） その他用途俌熱性・難燃性を活かして鋳物 の砂型や自動車のブレーキ等の摩擦材のバインダー, 断 熱材用のフェノールフォームとしても使われている。 ま た，炭化させた洔の残炭率の高いことを利用して C-C コンポジット（炭素をマトリックスとして炭素瀻維で強 化された材料）等にむ用いられている.

\section{(3)一新規技術・トピックス}

\section{3-1. 高分子量フェノール樹脂 ${ }^{101.11\}}$}

フェノール樹脂の数平均分子量は道常, 数百であり 1000 以上の高分子量化は従来は困䧼とされていた。こ れは, 分子内架橋によるゲル化が起こりやすいためであ る. しかし酶酸などの樹脂分子の搪がりやすい有機溶剂 中で反応を行うことにより, 数平均分子量が 3000 以上 のノボラック型フェノール樹脂の合成に成功している.

\section{3-2. 酵素重合 ${ }^{12), 13)}$}

ペルオキシダーゼを触媒に用いると, フェノールの重 合が起こる．この重合はフェノール単独でフェニル環が 直接, またはヒドロキシル基部分にエーテルの形で反応 し数平均分子量は数万～数十万のポリマーが得られる. 非常に高分子量である特徴があり, 今後の応用が期待さ れる.

3-3. カリックスアレン ${ }^{14)}$

カリックスアレンはフェノールとホルムアルデヒドよ り生成する環状オリゴマーで 4 量体から 8 量体までの 合成法が確立されている，包接化合物として分子・イオ ン認識機能への応用が仾究され, アルカリ金属, $\mathrm{C}_{60}$ フ ラーレンの識別能を示した。 また，ポリエチレングリ コールとロタキサン構造を取ることが確認されてい $3^{(5)}$.

\section{3-4. ベンゾオキサジン樹脂 ${ }^{16,17)}$}

フェノール樹脂にホルマリンと第一級アミンを反応さ せるとフェノール性水酸基とフェノール環オルト位の間 にオキサジン環を生成する.こうして得られた樹脂は加 熱によりオキサジン環が開環し架橋する. 架橋反応が縮 合反応でなく, 付加反応なので硬化時にガス発生がない 利点がある. また，エポキシ樹脂のように分子骨格を設 計できる点も有利である．この樹脂の特性は通常のフェ ノール樹脂同等以上であることか確認されている.

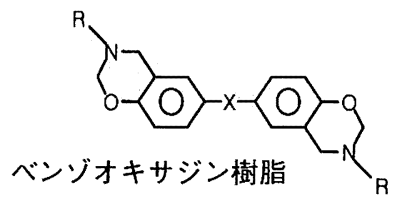

\section{3-5. 高品質瀻維状活性炭 ${ }^{18)}$}

フェノール樹脂を焼成して得られる活性炭は細孔分布 
がシャープであり，精密に制御できる特長をもってい る. 特にフェノール樹脂繊維を原料とする活性炭では吸 着速度が速く, 硬度が高く, 微粉が少ない. また形状屯 クロス, ペーパー, チョップ, フェルトなどさまざまな 形態のものを作ることができる. 食品脱色用, 水中の卜 リハロメタンやカビ臭除去, 有機電解質電極等に使用さ れている.

3-6. アモルファスカーボン複雑形状品 ${ }^{19)}$

従来アモルファスカーボン複雑形状品は, フェノール 樹脂粉末を圧縮成形し加熱硬化後，切削加工したものを 焼成して得ていたが，フィラーを含まず射出成形できる フェノール樹脂粉末が開発された. この樹脂は水中で硬 化剤存在下に奬濁重合反応することで硬化剤を均一分散 させ，樹脂の粒子径を制御することにより優れた粉体流 動性をむたせている．これにより複雑形状を切削加工な しで得ることができるようになった，アモルファスカー ボンは軽量で非常に硬く化学的に安定で, 気孔が少なく 気液体透過率が低い，また熱膨張係数が低く耐磨耗性に あ優れる特長をむつ.

3-7. フェノールーシリカ系有機無機ハイブリッド20)

フェノール樹脂溶液中でテトラメトキシシランの加水 分解・重縮合させることにより約 $5 \mathrm{~nm}$ のシリカ粒子を 均一分散した樹脂が得られる。シリカ含有率 $10 \mathrm{wt} \%$ 程 度でも曲げ強度・曲げ伸び率が 2 倍近く向上する.

\section{3-8. ラジカル硬化型フェノール樹脂21)}

フェノールはラジカルトラップ剤として働くため, フェノール樹脂のラジカル硬化は困難と考えられてい た.フェノール樹脂のヒドロキシル基の一部とグリシジ ルメタクリレートを反応させメタクリル基をグラフトさ せた樹脂は, 分子中にフェノール性水酸基をむつにむか かわらず過酸化物でガス発生のない硬化ができることが わかった。

\section{3-9. リサイクル}

熱硬化性樹脂のリサイクルは重要な課題である．この 対策として硬化物を粉末化して, 燃料やフィラー, カー ボン前駆体 ${ }^{22)}$ に使う方法, 高温で分解してエポキシ化し て再利用する方法 ${ }^{23)}$, 硬化物を原料フェノールモノマー に溶解してフェノール樹脂を合成する方法 ${ }^{24)}$, 超臨界水 中で分解し原料に戻す方法 ${ }^{25)}$ 等が検討されている.

\section{(4) 一後の技術動向}

強鞄性, さらなる耐熱性, 加工サイクルの短縮, リサ
イクルがフェノール樹脂の今後の課題である。これらの 問題に対して新規変性技術, 精密合成, 硬化制御技術の 研究が進められており, 高性能・高機能樹脂としての フェノール樹脂が発展していくものと期待される.

\section{文献}

1) 山田正栄：熱硬化性樹脂, 13(3), 178 (1992)

2) 池田信二, 大井慶二：第 41 回熱硬化性樹脂講演討論会講演 要旨集, p. 133 (1991)

3) 昭和高分子(株): 特開平 1-103646

4) 石田 保, 矢元正俊, 斉藤英紀：第 44 回熱硬化性樹脂講演 討諭会講演要旨集, p. 101 (1994)

5) 石田 保: $95 / 6$ 高分子可能性講座講演要旨集, p. 39 (1996)

6) 加藤宣勝：ネットワークポリマー, 17(1), 13 (1996)

7) 八木茂幸：企面実装技術 6 月特大号, p. 44 (1997)

8) 飯田隆久: 電子材料, 35(10), 45 (1996)

9）東崎栄造：回路実装学会誌, 12(4), 210 (1997)

10) 山岸忠明, 伊藤慎悟, 一木直樹, 山下晶平, 石田真一郎, 中 本義章, 野本雅弘：第 42 回熱硬化性樹脂講演討論会講演要 旨集, p. 29 (1992)

11) 山岸忠明, 野木雅弘, 海老池孝史, 山下晶平, 中本義章, 石 田真一郎：熱硬化性樹指, 15(3), 143 (1994)

12）小林四郎, 正由晋一郎, 宇山 浩：有機合成化学協会誌, 52(9), 754 (1994)

13) H. Uyama, H. Kurioka, J. Sugihara, S. Kobayashi: Bull. Chem. Soc. Jpn., 69(1), 189 (1996)

14）新海征治：ネットワークポリマー, 17(4), 169 (1996)

15）山岸忠明, 河原明彦, 石田真一郎, 中本義章：第 45 回熱硬 化性樹脂講演討論会講演要旨集, p. 41 (1995)

16) X. Ning, H. Isida: J. Polm. Sci., Part A, 32, 1121 (1994)

17) H. Ishida, D. J. Allen: J. Polm. Sci., Part B, 34, 1019 (1996)

18) 田中栄治：機能材料, 17(2), 13 (1997)

19）伊吹 洋: 機能材料, 17(10), 39 (1997)

20）宇佐見祐章，原口和敏：Polym. Prepr. Jpn., 46(11), 2883 (1997)

21）岡沼雅子, 中村克敏, 大鳥利行：第 46 回ネットワークポリ マー講演討論会講演要旨集, p. 183 (1996)

22）寒川喜光, 中野達明, 北川和男, 佐藤昌利, 島村哲朗: 熱硬 化性樹脂 16(4), 190 (1995)

23）島村哲朗, 寒川喜光, 北川和男, 中野達明, 佐藤昌利: 熱硬 化性樹脂 16(4), 183 (1995)

24) 松本明博, 内山喜三雄, 長谷川喜一, 大塚恵子, 福田明徳: 日本接着学会誌 32(3), 86 (1996)

25) 新井邦夫, 阿尻雅文, 後藤純也, 大鳥利行: 化学工学会第 30 回秋季大会研究発表講演要旨集 [第 1 分冊]; p. 252 (1997)

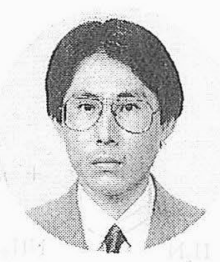

中村克敏 住友ベークライト(株)基礎 研究所 (245-0052 横浜市戸㴚区秋 葉町 495）主任研究員 1986 年名古屋工業大学工学部合成化 学科卒, 1988 年同大大学院工学研究 科修士課程修了, 1988 年住友べーク ライト(株)入社, 1993 年より現職. 専門は高分子合成化学. 〈趣味〉作曲, コンピュータミュージック。 